\title{
Reserves to increase beef production and their use
}

\author{
Leonid Kibkalo
}

Kursk State Agrarian Academy named after I.I. Ivanov, 70 Karl Marks street, Kursk, 305021, Russia

\begin{abstract}
The studies were carried out on three groups of superreplacement heifers of the Simmental breed, which were impregnated at the body weight of $360 \mathrm{~kg}$. In the first group there were 32 unimpregnated heifers, in the second -28 heifers, in the third -30 heifers. The heifers of the first group after growing at the age of 18 months were taken for meat. 56 heifers gave the crop. The heifers were transferred for reproduction, and the bull-calves were put on cultivation and further fattening. To obtain well-fed animals, special diets were made so that the average daily gain was at least $650-700 \mathrm{~g}$. After calving, the cows of the second group were taken for meat, and the cows of the third group were put on a 3-month fattening, and then taken for meat. The pre-slaughter weight of animals of the first group was 52 $\mathrm{kg}$ lower than that of animals of the second group and $104.7 \mathrm{~kg}$ lower than that of the third group. The difference was statistically significant at $\mathrm{P}>0.999$. The interior fat mass was higher in the carcasses of cows of the second group by 1.1 and $3.2 \mathrm{~kg}$ compared to the animals of the third and first groups. The carcass yield was almost at the same level slightly ahead of the animals of the first group. Their slaughter yield was $60.1 \%$, in other groups $-58.8-59.6 \%$. The meatiness ratio was slightly higher in animals of the first group. The carcass weight of the first-calf heifers of the third group was $27.4 \mathrm{~kg}$ higher than that of the second group. Compared to the first group, this figure is higher by $52.6 \mathrm{~kg}$. Specific carcass meat weight of the animals of the third group was $82.75 \%$, which is higher than in the second and first groups by $0.41-0.85 \%$, respectively. Heavy cowbanes weighing 32.6 and $40.4 \mathrm{~kg}$ were obtained from the animals. The skin of animals of the third group was 3.5-21.6 dm $\mathrm{dm}^{2}$ larger in area than of the animals of the second and first groups. Feeder bull-calves $(n=27)$ had a removable mass of $532 \mathrm{~kg}$. Heavy $(282.3 \mathrm{~kg})$ carcasses of good morphological composition were obtained from them. The sales revenue from first-calf heifers (second group) was higher than fattened heifers by $10.4 \%$, and in comparison with fattened animals after calving (third group) it was lower by $9.4 \%$. From the sale of one cow with a crop, 2.9 times more profit was received than from the sale of a heifer.
\end{abstract}

\section{Introduction}

One of the main sources of increasing meat production in the country is beef obtained from animals of dairy and dairy-meat breeds (Dunin et al., 2020).

The needs of the population of the country should be met mainly through their own production. To this end, it is necessary to implement a system of large-scale measures in two main areas: first, to increase the intensity of the use of fattening cattle from dairy herds by at least $30-40 \%$. This means increasing meat production per structural head and bringing the average body weight of livestock sold per cattle meat to 420-450 $\mathrm{kg}$ or more. Second, to increase the number of meat cattle and increase the share of meat cattle breeding in beef production from 2.0 to $20-25 \%$.

Beef production has increased significantly in recent years. The share of beef in the total meat production is $42 \%$, and in some regions - more than $45 \%$. However, the level of beef production in the country still does not meet the growing needs of the population and does not exhaust the potential for cattle breeding (Zadnepryansky, 2014). The yield of meat in the slaughter weight per one head of livestock is slightly more than $60 \mathrm{~kg}$, while with the correct cultivation and intensive fattening it is possible to get above $80 \mathrm{~kg}$.

At the moment, the potential of the industry is used only by $65-70 \%$ (Kibkalo, 2019; Kibkalo, 2019).

At the same time, the growing demand for meat requires the maximum use of all reserves to increase its production. Animal husbandry has shown the effectiveness of the use of superreplacement heifers for single calving. According to some authors, the matting of superreplacement heifers is practiced when they reach the age of 14-15 months. After obtaining the crop, they are put on feed. This method of using single cows is presents some scientific and economic interest.

Further improvement of the efficiency of the industry will depend on increasing the productivity of livestock by improving its feeding and maintenance conditions. This, in turn, will significantly increase beef production in the country and increase the economy of the industry (Katmakov, Anisimova, 2014).

\section{Problem statement}

Beef is the main source of increased meat production for the country's population. On average, each person should consume $80 \mathrm{~kg}$ of meat per year, including $32 \mathrm{~kg}$

\footnotetext{
Corresponding author: Kibkaloli2009@ rambler.ru
} 
(40\%) of beef. In fact, we consume $12-18 \mathrm{~kg}$, i.e. half the norm. Therefore, increasing beef production is a priority for producers.

In this regard, additional domestic reserves should be sought to increase beef production. Such a reserve, in our opinion, is the use of superreplacement heifers for single calving and putting the first-calf fed heifers for meat after calving.

Thus, from a scientific and practical point of view, the study of the use of superreplacement heifers as an additional reserve for increasing beef production is quite relevant.

\section{Subject of the study}

Until now, some of the superreplacement heifers are handed over for slaughter with an insufficiently high body weight. We consider it appropriate to impregnate such heifers at an early age (14-16 months) to receive additional calves one time. This use of superreplacement heifers makes it possible to increase beef production due to an increase in the body weight of animals, since in this case not 17-18-month-old (310-340 kg) heifers, but young cows with a body weight of $450-500 \mathrm{~kg}$ and higher, are put for slaughter. Besides, the number of young animals for growing and fattening is significantly increasing.

By changing the level of feeding of the first-calf heifers, we wanted to know whether young single cows give weaker calves, and how they grow by the periods of breeding and fattening.

To accelerate the rate of herd reproduction, provide fattening farms with livestock and increase beef production, it is necessary to use superreplacement heifers for single calving.

\section{Purpose of the study}

To search for reserves and use superreplacement heifers and single cows to increase beef production.

\section{Research methods}

The study utilized zootechnical and special research methods, including the methods that meet the GOST requirements. The variation statistics method was used to process the obtained data. The methodological basis of the study included the scientific works of domestic and foreign authors on the study of meat productivity of young cattle of combined breeds.

\section{Research results}

The studies were carried out on superreplacement heifers of Simmental breed. For the experiment, 90 superreplacement heifers were selected, which were given for feeding at the age of 10-12 months with a body weight of 250-270 kg. They were grown for 6 months and impregnated with the semen of bull-calves of the Simmental breed. The body weight of heifers during impregnation was $355-365 \mathrm{~kg}$. A cervical insemination technique was used. As a result, 58 heifers or $65 \%$ got impregnated. All animals were divided into three groups: in the first (control) there were 32 unimpregnated heifers, in the second -28 heifers, which were planned for meat after calving and colostral period, in the third 30 heifers, which were planned for meat after calving and three-month fattening.

It was expected to obtain well-fed animals, as a result of which the diets were 600-700 g to obtain average daily gains. The animals of the second and third groups compared to their peers of the first group grew more intensively only during the exact period, which is explained by the hyperfunction of all systems and organs with the beginning of impregnation.

Thus, 56 heifers gave a full-fledged crop. The heifers were handed over for reproduction, and the bull-calves (27 heads) were put on cultivation and further fattening.

All heifers of the first group were placed for meat at the age of 23 months, the first-calf heifers of the second group - at 26 months, the third - at 29 months.

Control slaughter materials are shown in Table 1.

Table 1. Results of control slaughter

\begin{tabular}{|l|c|c|c|}
\hline \multicolumn{1}{|c|}{ Indicator } & \multicolumn{3}{c|}{ Groups of animals } \\
\cline { 2 - 4 } & first & second & third \\
\hline Removable body weight, $\mathrm{kg}$ & $468.3 \pm 5.7$ & $522.6 \pm 7.3$ & $576.4 \pm 6.8$ \\
\hline Pre-slaughter body weight, $\mathrm{kg}$ & $460.5 \pm 4.8$ & $512.5 \pm 6.2^{*}$ & $565.2 \pm 5.9^{*}$ \\
\hline Hot carcass weight, kg & $268.0 \pm 3.9$ & $293.6 \pm 4.5^{*}$ & $321.0 \pm 5.2^{*}$ \\
\hline Interior fat weight, kg & $9.1 \pm 2.4$ & $12.3 \pm 3.6$ & $11.6 \pm 4.1$ \\
\hline Slaughter weight, kg & $277.1 \pm 4.9$ & $305.9 \pm 5.8$ & $332.2 \pm 6.4$ \\
\hline Carcass yield, \% & $58.2 \pm 2.4$ & $57.3 \pm 1.6$ & $56.8 \pm 1.3$ \\
\hline Fat yield, \% & $1.9 \pm 0.05$ & $2.4 \pm 0.06$ & $1.9 \pm 0.07$ \\
\hline Slaughter yield, \% & $60.1 \pm 3.7$ & $59.6 \pm 3.4$ & $58.8 \pm 2.5$ \\
\hline
\end{tabular}

$$
* \mathrm{P}>0.999 \text {; }
$$

The table shows that the pre-slaughter weight of animals of the first group is $52 \mathrm{~kg}$ lower than that of animals of the second group and $104.7 \mathrm{~kg}$ lower than that of the third group. The difference is statistically significant $(\mathrm{P}>0.999)$.
The most important indicator, the carcass weight, of the first-calf heifers of the third group was $321.0 \mathrm{~kg}$, which is $27.4 \mathrm{~kg}$ higher than that of the animals of the second group. In the heifers of the first group this figure was $268.0 \mathrm{~kg}$, which is $53 \mathrm{~kg}$ lower compared to the third group. 
The slaughter yield of the animals of the first group was $60.1 \%$, which is $0.5-1.3 \%$ higher than in the other two groups, respectively.

The ratio of muscle tissue, bones, tendons in carcasses is important for practical application (Table 2).

Table 2. Morphological composition of animal carcasses

\begin{tabular}{|l|c|c|c|}
\hline \multirow{1}{*}{ Indicator } & \multicolumn{3}{|c|}{ Groups of animals } \\
\cline { 2 - 4 } & first & second & third \\
\hline $\begin{array}{l}\text { Chilled carcass } \\
\text { weight, } \mathrm{kg}\end{array}$ & $266.1 \pm 2.8$ & $291.5 \pm 4.2$ & $318.7 \pm 4.8$ \\
\hline Boneless meat, $\mathrm{kg}$ & $217.9 \pm 2.2$ & $240.0 \pm 2.7$ & $263.7 \pm 2.4$ \\
\hline $\begin{array}{l}\text { Specific weight, } \\
\%\end{array}$ & 81.90 & 82.34 & 82.75 \\
\hline Bones, $\mathrm{kg}$ & $45.7 \pm 0.42$ & $49.2 \pm 0.41$ & $53.8 \pm 0.52$ \\
\hline $\begin{array}{l}\text { Specific weight, } \\
\%\end{array}$ & 17.20 & 16.87 & 16.90 \\
\hline $\begin{array}{l}\text { Tendons and } \\
\text { veins, kg }\end{array}$ & 2.39 & 2.30 & 1.12 \\
\hline $\begin{array}{l}\text { Specific weight, } \\
\%\end{array}$ & 0.9 & 0.79 & 0.35 \\
\hline Meatiness ratio & 5.82 & 4.87 & 4.91 \\
\hline
\end{tabular}

As a result of boning it was found that the specific weight of the boneless meat in the carcasses of animals of the third group is $82.75 \%$, which is higher than in the second and first groups by $0.41-0.85 \%$, respectively. The specific weight of bones is almost at the same level in all groups.

The specific weight of tendons and veins in fattened heifers is $0.44-0.55 \%$ lower compared to other groups.

The meatiness ratio is higher in animals of the first group.

After the control slaughter of animals, the carcasses were sawed into two halves, and then into separate parts (junctures). The specific weight of junctures and their morphological composition in relation to the total weight of the carcass depends on the breed, sex of animals, fatness, age. In this regard, we studied the carcasses by anatomical parts. The obtained data are shown in Table 3.

In accordance with the approved methodology of the All-Russian Institute of Animal Husbandry, the carcasses were divided into five parts (junctures): neck, shoulder, back and ribs, shell, hips. The boneless meat and bones were determined in each of them. The carcasses of animals of the third experimental group contain more boneless meat by $1.09-1.2 \%$ compared to the first and second groups. The boneless meat yield is

Table 4 shows that the cows of the third group have a slightly higher specific weight of the hip part. The animals of the first and second groups slightly differ in this part. Back and ribs are better developed in the animals of the third group. Back and ribs and Shell parts are more developed in the animals of the first and second groups. As for the neck part, here preference should be given to the animals of the second group (first-calf heifers that were placed for meat after calving). slightly higher in the back and hip parts. The animals of the third group are characterized by more developed hip part and the entire posterior third of the body.

Table 3. Study by natural anatomical parts

\begin{tabular}{|c|c|c|c|c|c|c|}
\hline \multirow[t]{2}{*}{ Indicator } & \multicolumn{6}{|c|}{ Half carcass parts } \\
\hline & $\begin{array}{l}\text { Z̃ } \\
\text { Z }\end{array}$ & $\frac{\bar{d}}{\frac{0}{3}}$ & 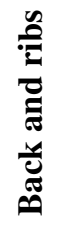 & $\overline{\bar{d}}$ & $\stackrel{\varrho}{气}$ & ) \\
\hline \multicolumn{7}{|c|}{ First group } \\
\hline $\begin{array}{l}\text { Total } \\
\text { weight, } \mathrm{kg}\end{array}$ & 12.1 & 23.3 & 38.2 & 12.1 & 47.6 & 132.9 \\
\hline $\begin{array}{l}\text { Including } \\
\text { boneless } \\
\text { meat, kg }\end{array}$ & 9.9 & 18.6 & 29.5 & 10.9 & 40.4 & 108.9 \\
\hline$\%$ & 8.7 & 17.1 & 27.0 & 10.1 & 37.1 & 100 \\
\hline Bones, kg & 2.2 & 4.7 & 8.7 & 1.2 & 7.2 & 24.0 \\
\hline$\%$ & 9.2 & 19.8 & 36.3 & 5.4 & 29.3 & 100 \\
\hline \multicolumn{7}{|c|}{ Second group } \\
\hline $\begin{array}{l}\text { Total } \\
\text { weight, } \\
\mathrm{kg}\end{array}$ & 14.2 & 25.3 & 41.1 & 13.8 & 50.9 & 145.7 \\
\hline $\begin{array}{l}\text { Including } \\
\text { boneless } \\
\text { meat, kg }\end{array}$ & 11.9 & 20.6 & 31.5 & 12.1 & 43.5 & 120 \\
\hline$\%$ & 9.9 & 17.0 & 26.0 & 10.0 & 36.1 & 100 \\
\hline $\begin{array}{l}\text { Bones, } \\
\mathrm{kg}\end{array}$ & 2.3 & 4.7 & 9.6 & 1.7 & 7.4 & 25.7 \\
\hline$\%$ & 9.3 & 18.2 & 36.8 & 6.5 & 29.2 & 100 \\
\hline \multicolumn{7}{|c|}{ Third group } \\
\hline $\begin{array}{l}\text { Total } \\
\text { weight, } \\
\text { kg }\end{array}$ & 14.4 & 27.6 & 45.1 & 15.1 & 57.1 & 159.3 \\
\hline $\begin{array}{l}\text { Including } \\
\text { boneless } \\
\text { meat, } \mathrm{kg}\end{array}$ & 11.9 & 22.7 & 34.6 & 13.5 & 49.1 & 131.8 \\
\hline$\%$ & 9.1 & 17.2 & 26.3 & 10.2 & 37.2 & 100 \\
\hline Bones, kg & 2.5 & 4.9 & 10.5 & 1.6 & 8.0 & 27.5 \\
\hline & 9.0 & 18.0 & 38.2 & 5.6 & 29.2 & 100 \\
\hline
\end{tabular}

Thus, the carcasses of animals of the third group (first-calf heifers after a three-month fattening) had better meat qualities and indicators of more valuable parts and higher varieties of meat.

A better understanding of the difference in groups for individual junctures may be obtained after studying the specific weight of the half carcass parts (Table 4).

Table 4. Specific weight of half carcass parts (in \% of half carcass weight)

\begin{tabular}{|l|c|c|c|}
\hline \multirow{2}{*}{$\begin{array}{l}\text { Half carcass } \\
\text { parts }\end{array}$} & \multicolumn{3}{|c|}{ Groups of animals } \\
\cline { 2 - 4 } Neck & first & second & third \\
\hline Shoulder & 9.10 & 9.74 & 9.03 \\
\hline Back and ribs & 17.53 & 17.36 & 17.32 \\
\hline Shell & 28.74 & 28.21 & 28.31 \\
\hline Hips & 9.10 & 9.47 & 9.48 \\
\hline
\end{tabular}


We studied the meat completeness of the individual parts of the half carcass. The obtained data are summarized in Table 5.

Table 5. Quantity of boneless meat in different junctures per $\mathrm{kg}$ of bones, $\mathrm{kg}$

\begin{tabular}{|l|c|c|c|}
\hline \multirow{2}{*}{$\begin{array}{l}\text { Half carcass } \\
\text { parts }\end{array}$} & \multicolumn{3}{|c|}{ Groups of animals } \\
\cline { 2 - 4 } Neck & first & second & third \\
\hline Shoulder & 4.50 & 5.17 & 4.76 \\
\hline Back and ribs & 3.95 & 4.38 & 4.63 \\
\hline Shell & 3.39 & 2.28 & 3.29 \\
\hline Hips & 9.09 & 7.12 & 8.43 \\
\hline
\end{tabular}

Table 5 shows that the amount of boneless meat in different junctures is different. The carcasses of the animals of the third experimental group contain higher boneless meat content. First of all, this concerns the most valuable junctures of the carcass - shell and hip. One $\mathrm{kg}$ of bones contains 8.43 and $6.13 \mathrm{~kg}$ of boneless meat, respectively. At the same time, the shell part per $1 \mathrm{~kg}$ of bones accounts for $9.08 \mathrm{~kg}$ of boneless meat in the animals of the first group. There are some differences in other parts of the half carcass.

In our studies we assessed the quality of carcasses and meat taking into account linear measurements of carcasses and their anatomical parts. The assessment was carried out in accordance with the procedure of the AllRussian Research Institute of Animal Husbandry as follows:

$\mathrm{K}_{1}$ (complete boneless meat of the carcass) = carcass weight/carcass length $\times 100$;

$\mathrm{K}_{2}$ (hip fleshing) = hip circumference/hip length $\times 100$.

The obtained data are shown in Table 6.

Table 6. Meatiness indices of fattened animal carcasses

\begin{tabular}{|l|c|c|c|}
\hline \multirow{2}{*}{ Indicator } & \multicolumn{3}{|c|}{ Groups of animals } \\
\cline { 2 - 4 } & first & second & third \\
\hline $\begin{array}{l}\text { Chilled carcass } \\
\text { weight, } \mathrm{kg}\end{array}$ & 266.1 & 291.5 & 318.7 \\
\hline Carcass length, cm & 129.3 & 136.4 & 143.5 \\
\hline hip & 95.6 & 97.4 & 97.8 \\
\hline carcass & 224.9 & 233.8 & 241.3 \\
\hline $\begin{array}{l}\text { Hip circumference, } \\
\text { cm }\end{array}$ & 105.9 & 107.8 & 108.6 \\
\hline $\mathrm{K}_{1}$ & 118.3 & 124.6 & 132.0 \\
\hline $\mathrm{K}_{2}$ & 110.7 & 110.6 & 111.0 \\
\hline
\end{tabular}

The studies showed that different weights of animal carcasses influenced the meat completeness of carcasses. The meat completeness of the animal carcasses that were fed for three months after calving is more pronounced (third group). These animals had more pronounced hip fleshing. They were also distinguished by the the meat completeness of the hip. Thus, more valuable carcasses are obtained from the first-calf heifers of the third group. Improved meat content of the carcass depends on its increased weight, which entails increased yield of edible parts.

The method used to assess carcasses using linear measurements allows determining the meat qualities of slaughter animals without boning.

Cattle skins are the main raw materials for leather production. In this regard, we studied the commercial and technological properties of fresh animal skins of all three groups (Table 7).

Table 7. Characteristics of fresh skins of experimental animals

\begin{tabular}{|c|c|c|c|}
\hline \multirow[t]{2}{*}{ Indicator } & \multicolumn{3}{|c|}{ Groups of animals } \\
\hline & first & second & third \\
\hline $\begin{array}{l}\text { Weight of fresh } \\
\text { skin, kg }\end{array}$ & $32.6 \pm 0.52$ & $40.4 \pm 0.48$ & $46.3 \pm 0.59$ \\
\hline $\begin{array}{l}\text { Yield of fresh } \\
\text { skin, } \%\end{array}$ & 7.1 & 7.9 & 8.2 \\
\hline Width, cm & 180.3 & 185.2 & 186.4 \\
\hline Length, $\mathrm{cm}$ & 210.4 & 214.6 & 215.1 \\
\hline Area of skin, $\mathrm{dm}^{2}$ & $379.3 \pm 4.5$ & $397.4 \pm 5.6$ & $400.9 \pm 6.2$ \\
\hline $\begin{array}{l}\text { Skin thickness, } \\
\text { mm: } \\
\text { - shoulder }\end{array}$ & $7.3 \pm 0.22$ & $7.6 \pm 0.31$ & $7.7 \pm 0.36$ \\
\hline - belly & $8.1 \pm 0.28$ & $8.3 \pm 0.39$ & $8.3 \pm 0.38$ \\
\hline - shell & $8.7 \pm 0.36$ & $8.8 \pm 0.37$ & $8.8 \pm 0.39$ \\
\hline $\begin{array}{l}\text { Skinfold } \\
\text { thickness, \% }\end{array}$ & 16.0 & 13.6 & 12.5 \\
\hline $\begin{array}{l}\text { Weight of } 1 \mathrm{dm}^{2} \text {, } \\
\mathrm{g}\end{array}$ & 85.9 & 101.6 & 115.4 \\
\hline $\begin{array}{l}\text { Skin area per } 1 \\
\mathrm{~kg} \text { of body } \\
\text { weight, } \mathrm{dm}^{2}\end{array}$ & 0.82 & 0.77 & 0.71 \\
\hline
\end{tabular}

In our studies the heavy skins are obtained from firstcalf heifers, who were fed for three months after calving and then placed for meat. Heavy skins weighing 32.6 and $40.4 \mathrm{~kg}$ were also obtained from animals of the first and second groups.

The value of the skin for processing is characterized by its area and thickness. The animals of the third group were characterized by a larger area. The area of their skin was $3.5-21.6 \mathrm{dm}^{2}$ larger than that of the animals of the second and first groups.

Thus, under good feeding and maintenance conditions it is possible to obtain high-quality leather raw materials much needed by the leather industry.

All bull-calves $(n=27)$ that were put for cultivation were removed from fattening at the age of 18 months. Their body weight averaged $532 \mathrm{~kg}$. During the growing and feeding period the bull-calves consumed 3816 energy feed units and $365 \mathrm{~kg}$ of digestible protein. The animals retained high growth energy during the entire fattening period. Their average daily gain made more than $920 \mathrm{~g}$. Heavy $(282.3 \mathrm{~kg})$ meat carcasses of good morphological and chemical composition were obtained from them. A profit was made during the sale of each bull-calf. 
The sales revenue of the first-calf heifers is higher than that of fattened animals by 7,168 rubles $(10.4 \%)$, and in comparison with the fattened animals after calving - lower by 7,101 rubles $(9.4 \%)$. At the same time, the cost-effectiveness of using single cows (after fattening) and their offspring for beef production is much higher than the fattening heifers. The sale of one cow with a crop gave 2.9 times more profit than from the sale of a heifer.

\section{Conclusions}

Thus, the widespread use of superreplacement heifers for single production of calves may be considered a large reserve for increasing beef production.

It is cost-effective for farms to feed all culled heifers, especially the first-calf heifers after 3 months of fattening. Agricultural enterprises are thus making a profit. Profitability ranges from 27.1 to $38.2 \%$.

Feeding single cows and their offspring for beef production is more cost-effective when sold compared to fattened heifers.

Based on the obtained data it can be stated that quite viable calves are born from single cows at the age of 26 months, which at a fairly high level of feeding grow and feed well.

\section{References}

1. I.M. Dunin et al. Dairy and meat cattle breeding, 2, 2-7, (2020)

2. I.P. Zadnepryansky Bulletin of meat cattle breeding. All-Russian Research Institute of Meat Cattle Breeding. Theoretical and scientificpractical journal, 1 (84), 59-64, (2014)

3. P.S. Katmakov, E.I. Anisimova Bulletin of Ulyanovsk State Agricultural Academy: scientific and technical journal. 1 (25), 121-126, (2014)

4. L.I. Kibkalo et al. International journal of advanced biotechnology and research, 10(1), 3340, (2019)

5. L.I. Kibkalo et al. International Journal of Advanced Biotechnology and Research, 10(1), 26-32 (2019) 